\title{
The capability of organizational innovation: systematic review of literature and research proposals
}

\author{
A capacidade de inovação organizacional: revisão sistemática da \\ literatura e proposições para pesquisa \\ José Jaconias da Silva ${ }^{1}$ [C, Claudia Brito Silva Cirani² ${ }^{2}$ \\ ${ }^{1}$ Universidade Federal de Mato Grosso - UFMT, Cuiabá, MT, Brasil. E-mail: josejaconias@gmail.com \\ ${ }^{2}$ Universidade Nove de Julho - UNINOVE, Programa de Pós-graduação em Administração, São Paulo, SP, Brasil. \\ E-mail: claudiabscirani@gmail.com
}

How to cite: Silva, J. J., \& Cirani, C. B. S. (2020). The capability of organizational innovation: systematic review of literature and research proposals. Gestão \& Produção, 27(4), e4819. https://doi.org/10.1590/0104-530X4819-20

\begin{abstract}
The capability of organizational innovation is an important factor for the company to achieve a higher competitive performance. Understanding how innovation capability emerges, develops, and applies could bring important managerial and scientific contributions. This study investigates the main research results regarding the capability of organizational innovation, indicating some theoretical propositions for future studies, based on the systematic review of the literature. The research aimed to identify the determinants of organizational innovation capability and the context in which the studies are carried out. We conducted a systematic literature review based on the Web of Science database. We identified and analyzed 33 papers through the analysis of content. This study presents several research results regarding the capability of innovation in organizations, divided into internal, external and determinant aspects of innovation capability, as well as the collection of propositions for guiding a research project in depth in questions to be tested in future research. The study also brings practical contributions, as it shows in which context each study on determinants of identified innovation capability is applied, and points out the importance of innovation capability in small companies and in countries.
\end{abstract}

Keywords: Capability for innovation; Determinants of innovation capability; Systematic review; Propositions.

Resumo: A capacidade de inovação organizacional é um importante fator para empresa alcançar um desempenho competitivo superior, entender como a capacidade de inovação surge, se desenvolve e aplica, trazendo importantes contribuições gerenciais e científicas. Assim, este trabalho tem como objetivo identificar, com base na revisão sistemática da literatura, os principais resultados de pesquisa a respeito da capacidade de inovação organizacional, indicando algumas proposições teóricas para futuros estudos. E como problema de pesquisa - quais os fatores determinantes sobre capacidade de inovação organizacional e qual contexto essas pesquisas são realizadas A metodologia utilizada foi a revisão sistemática da literatura, utilizando como base de dados a Web of Science, onde 33 artigos científicos foram identificados e analisados por meio da análise de conteúdo. As contribuições científicas deste estudo são os vários resultados de pesquisa a respeito da capacidade de inovação em organizações, divididos em

Received May 5, 2018 - Accepted Sept. 11, 2018

Financial support: None.

This is an Open Access article distributed under the terms of the Creative Commons Attribution License, which permits unrestricted use, distribution, and reproduction in any medium, provided the original work is properly cited. 
aspectos internos, externos e determinantes da capacidade de inovação, bem como o levantamento de proposições capazes de guiar um projeto de pesquisa mais aprofundado em questões relevantes a serem testadas em pesquisas futuras. Também traz contribuições práticas, pois mostra em que contexto é mais aplicado cada um dos estudos sobre determinantes da capacidade de inovação identificado e aponta a importância da capacidade de inovação em pequenas empresas e em países.

Palavras-chave: Capacidade de inovação; Determinantes da capacidade de inovação; Revisão sistemática; Proposições.

\section{Introduction}

Innovation capability of a company is linked to the internal efforts of human, technological and organizational resources, combined with the ability to interact with the external environment to pursue resources, knowledge and skills to be incorporated into the organization to create new products and processes that are perceived and valued by stakeholders (Lawson \& Samson, 2001).

From the operational viewpoint, building capability of innovation is not a simple task, as it requires a decision-making process that drives the company efforts towards innovation and creates a culture of innovation among employees and within the organization as a whole. Operationally, innovation capability implies a team of motivated staff to build processes, products and services that could be valued to customers and suppliers (Henderson \& Clark, 1990), bringing evidence to the company and conditions of competitive advantage in the long term (Wernerfelt, 1984; Barney, 1991).

The ability to innovate could be studied in the internal environment, understanding how the capacities are originated, constructed, developed and managed (Schneckenberg et al., 2015) as well as in the external environment, directed to the relationship with suppliers, building links of socialization and trust, and sharing information to generate innovations (Kulangara et al., 2016).

Crossan \& Apaydin (2010) used the systematic literature review and identified the most common theories in studies on innovation capability, namely resource-based view, organizational learning, and network theory. The authors also identified determinants of innovation capability, grouping them into individual/group level, organizational level, and process level. Valladares et al. (2014) also identified determinants of innovation capability based on a systematic review of the literature, namely transformative leadership, strategic intent to innovate, people management for innovation, knowledge of customers and the market, strategic technology management, organizational structure, and project management.

In this sense, this study brings scientific contributions, as it presents updated results of several studies regarding the capability of innovation in organizations, divided into internal, external aspects and determinants of innovation capability, proposing guidance for research projects. This study also presents practical contributions, as it shows in which context each of the studies on identified determinants of innovation capability is applied and highlights the importance of innovation capability in small companies and in countries.

In this study, we conducted a systematic literature review, not only to construct a theoretical discussion about innovation capability in the internal and external environments of the organization and in the contexts of small companies and different countries, but also to identify the determinants of innovation capability, aiming to obtain 
subsidies for hypotheses to be tested in future studies. Based on the results of this study, we intended to answer the question: what are the determinants of organizational innovation capability and in which context are these studies carried out?

The systematic literature review is an important methodological tool when the subject to be researched is extensive. Nevertheless, it must be carried out with criteria and based on organized and clear steps (Tranfield et al., 2003). In this study, we selected 33 papers from the Web of Science database (Thomson Reuters Scientific), considering three categories: (1) papers review and meta analysis (05 papers); (2) most cited articles on the Web of Science (17 papers); (3) and more recent articles from journals with A1 extract from the Commission for the Improvement of Higher Education Personnel (CAPES) in Brazil (11 papers).

This study is structured as follows: introduction; theoretical reference with the conceptualization of innovation and capability for innovation; methodological procedures of the construction of the systematic literature review; the results and the discussion bringing the contributions of the literature to innovation capability in the internal and external environments and the determinants of the innovation capability and the relation of innovation capability in small companies and in different countries, as well as a connection of the studies reviewed and propositions for a framework of questions that could be investigated in detail in future studies in the field; and the final considerations.

\section{Innovation and innovation capability}

Innovation capability arises from the Resource-Based View (RBV) theory, which proposes that resources are strategic for competitive advantages (Barney, 1991). The RBV has a theoretical framework that allows identifying internally the company resources and capabilities to generate competitive advantages and thus prioritize them. Companies that could successfully assess their resources and capabilities perform better in the marketplace (Wernerfelt, 1984). Resources are crucial for enterprises that aim to achieve long-term competitive advantages (Barney, 1991).

The increasingly fierce competition, fostered by globalization and information technology, makes the RBV an important alternative for companies that want to innovate. However, innovation capability does not consists only of internal resources of the company, but also of external resources (Swink, 2006). Therefore, a new approach complements the RBV, the Dynamic Capabilities theory, proposing that not only resources and skills of the company could generate the competitive advantage, but also the processes of learning, knowledge, coordination and resource reconfiguration within the company and in contact with the company external environment (Teece et al., 1997).

Innovation contributes to competitive advantage for companies and therefore many researchers have sought to understand how to strengthen the company capability to innovate, as this make enterprises more competitive and perform better financially (Henderson \& Clark, 1990).

Before advancing the understanding of innovation capability, it is important to conceptualize innovation. A broad concept is presented below:

Production or adoption, assimilation and exploration of a novelty of added value in economic and social spheres; renewal and expansion of products, services and 
markets; development of new production methods; establishment of new management systems; it is both a process and a result. (Crossan \& Apaydin, 2010, p.1155).

Innovations are not only new products or better services, but also the success they could deliver in the market. Innovation capability could be understood as the ability to mobilize knowledge of employees in combination with other new knowledge, resulting in new products or processes (Kogut \& Zander, 1992).

The definition of innovation capability in administration science is always a challenge, since organizations, researchers and research areas (marketing, production engineering, strategy) have different perceptions about the subject. In a broad definition, Lawson \& Samson (2001) proposes that innovation capability refers to the capability to continually transform ideas and knowledge into new processes, products and systems of the organization into utilities for customers.

For Lawson \& Samson (2001), innovation capability concerns how companies could extract knowledge from routine exploration activities and innovative exploration activities. This means that the concept is related to the ability of companies to properly manage the internal resources of the company for innovation and at the same time seek knowledge and skills in the external environment.

Developing routines of activities that contribute to organizational innovation is not simple, as it requires planning to introduce a culture of innovation into the company. In order to innovate, companies need personnel who are capable of analyzing, interpreting and relating internally and with stakeholders identifying opportunities for sharing information and innovation (Henderson \& Clark, 1990).

\section{Methodology}

A systematic unbiased literature review was carried out using criteria based on clear and organized steps, which may be replicated by reviewers and other scientists, as well as a strategic tool to address the diversity of knowledge. This review is composed of three basic phases: planning, execution, and reporting and understanding (Tranfield et al., 2003).

In the planning phase, we established the research objectives and chose the database for the search - the Web of Science main collection (Thomson Reuters Scientific) - which is considered one of the most complete and comprehensive databases in social sciences, in addition to having the feature of citation counting, which facilitates the selection of articles (Crossan \& Apaydin, 2010).

In this phase, the search terms were defined. As the objective was to find articles on innovation capability, the terms in English were: innovation capability, ability to innovate, capabilities for innovation, capability for innovation, innovate ability, innovative ability, innovative capacities, innovation ability, innovation capability, innovative capabilities.

In the second phase - execution - all terms were entered into the Web of Science search space. The filters used were: the title, to make sure that the results contained only articles whose central theme dealt with innovation capability; the publication years available, from 1945 to 2017; the language in English; Business, Management, Economics and Finance; and document types articles and review. We obtained 617 search results. 
In the execution phase, the articles were grouped into three categories: $1^{\text {st }}$ category, review articles; $2^{\text {nd }}$ category, most cited articles (with at least 50 citations in the main Web of Science collection); and since articles published in recent years may have few citations, a $3^{\text {rd }}$ category was established based on the years 2015, 2016 and 2017, that is, the category of the most recent articles.

In order to refine the selection, the articles of scientific journals that were classified as A1 in the CAPIS Qualis extract were selected. Based on the criteria presented above, five articles from the $1^{\text {st }}$ category, 17 from the $2^{\text {nd }}$ category and 11 from the $3^{\text {rd }}$ category were selected for analysis. Thus, 33 scientific articles were included, which was the number of publications analyzed in this research.

Table 1 shows the authors, the number of citations (Cit), the journal and its Qualis classification ( $Q$ ), and the methodological approach. In some cases the journals were not evaluated by CAPES and therefore received the abbreviated classification of $\mathrm{N}$.

Table 1. Authors, journals and methodological approach to systematic literature review.

\begin{tabular}{|c|c|c|c|c|c|}
\hline Selection & Authors & Cit & Journal & $\mathbf{Q}$ & $\begin{array}{l}\text { Methodological } \\
\text { Approach }\end{array}$ \\
\hline \multirow{5}{*}{ Review } & (Saunila, 2016) & 01 & $\begin{array}{c}\text { International Journal of } \\
\text { Productivity and } \\
\text { Performance Management }\end{array}$ & A1 & Qualitative - Review \\
\hline & (Pattinson et al., 2016) & 00 & Management Learning & $\mathrm{N}$ & Qualitative - Review \\
\hline & (Slater et al., 2014) & 45 & $\begin{array}{c}\text { Journal of Product } \\
\text { Innovation Management }\end{array}$ & $\mathrm{N}$ & Qualitative - Review \\
\hline & $\begin{array}{c}\text { (Frishammar et al., } \\
\text { 2012) }\end{array}$ & 13 & $\begin{array}{l}\text { IEEE Transactions On } \\
\text { Engineering Management }\end{array}$ & $\mathrm{N}$ & Qualitative - Review \\
\hline & (Swink, 2006) & 61 & $\begin{array}{c}\text { Research-Technology } \\
\text { Management }\end{array}$ & $\mathrm{N}$ & Qualitative - Review \\
\hline \multirow{14}{*}{$\begin{array}{l}\text { Most } \\
\text { Cited by } \\
\text { Web Of } \\
\text { Science }\end{array}$} & $\begin{array}{l}\text { (Subramaniam \& } \\
\text { Youndt, 2005) }\end{array}$ & 80 & $\begin{array}{l}\text { The Academy of } \\
\text { Management Journal }\end{array}$ & A1 & Quantitative \\
\hline & (Calantone et al.,2002) & 61 & $\begin{array}{l}\text { Industrial marketing } \\
\text { management }\end{array}$ & \multicolumn{2}{|c|}{ A1 Qualitative/Quantitative } \\
\hline & $\begin{array}{c}\text { (Romijn \& Albaladejo, } \\
\text { 2002) }\end{array}$ & 24 & Research Policy & $\mathrm{N}$ & Quantitative \\
\hline & (Lin, 2007) & 22 & $\begin{array}{c}\text { International Journal of } \\
\text { Manpower }\end{array}$ & A1 & Quantitative \\
\hline & $\begin{array}{c}\text { (Hagedoorn \& } \\
\text { Duysters, 2002) }\end{array}$ & 22 & $\begin{array}{c}\text { Journal of Management } \\
\text { Studies }\end{array}$ & A1 & Quantitative \\
\hline & $\begin{array}{c}\text { (Prajogo \& Ahmed } \\
2006)\end{array}$ & 11 & R\&D Management & $\mathrm{N}$ & Quantitative \\
\hline & (Sher \& Yang, 2005) & 86 & Technovation & A1 & Quantitative \\
\hline & (Forsman, 2011) & 76 & Research Policy & $\mathrm{N}$ & Quantitative \\
\hline & (Fan, 2006) & 76 & Technovation & A1 & Qualitative \\
\hline & $(\mathrm{Li}, 2009)$ & 75 & Research Policy & $\mathrm{N}$ & Quantitative \\
\hline & (Guan et al., 2006) & 72 & $\begin{array}{l}\text { European Journal of } \\
\text { Operational Research }\end{array}$ & A1 & Quantitative \\
\hline & (Nassimbeni, 2001) & 66 & Research Policy & $\mathrm{N}$ & Quantitative \\
\hline & (Wang et al., 2008) & 63 & Technovation & A1 & Quantitative \\
\hline & $\begin{array}{l}\text { (Perdomo-Ortiz et al., } \\
\text { 2006) }\end{array}$ & 63 & Technovation & $\mathrm{A} 1$ & Quantitative \\
\hline
\end{tabular}


Table 1. Continued...

\begin{tabular}{|c|c|c|c|c|c|}
\hline Selection & Authors & Cit & Journal & $\mathbf{Q}$ & $\begin{array}{l}\text { Methodological } \\
\text { Approach }\end{array}$ \\
\hline & $\begin{array}{c}\text { (Rohrbeck \& } \\
\text { Gemünden, 2011) }\end{array}$ & 58 & $\begin{array}{l}\text { Technological Forecasting } \\
\text { and Social Change }\end{array}$ & A1 & Qualitative \\
\hline & (Sen \& Egelhoff, 2000) & 55 & $\begin{array}{l}\text { IEEE Transactions On } \\
\text { Engineering Management }\end{array}$ & $\mathrm{N}$ & Quantitative \\
\hline & (Lai \& Shyu, 2005) & 50 & Technovation & A1 & Quantitative \\
\hline \multirow{11}{*}{$\begin{array}{c}\text { Most } \\
\text { Recent } \\
(2015 \text {, } \\
2016 \text {, } \\
2017)\end{array}$} & (Foroudi et al., 2016) & 02 & $\begin{array}{l}\text { Journal of Business } \\
\text { Research }\end{array}$ & A1 & Quantitative \\
\hline & $\begin{array}{l}\text { (Khedhaouria \& } \\
\text { Thurik, 2017) }\end{array}$ & 00 & $\begin{array}{l}\text { Technological Forecasting } \\
\text { and Social Change }\end{array}$ & A1 & Quantitative \\
\hline & $\begin{array}{c}\text { (Kulangara et al., } \\
2016)\end{array}$ & 00 & $\begin{array}{l}\text { International Journal of } \\
\text { Operations \& Production } \\
\text { Management }\end{array}$ & A1 & Quantitative \\
\hline & (Lai et al., 2015) & 00 & $\begin{array}{l}\text { Journal of Business } \\
\text { Research }\end{array}$ & A1 & Quantitative \\
\hline & (Liu et al., 2015) & 00 & $\begin{array}{l}\text { Journal of Business } \\
\text { Research }\end{array}$ & A1 & Quantitative \\
\hline & (Oura et al., 2016) & 03 & $\begin{array}{c}\text { International Business } \\
\text { Review }\end{array}$ & A1 & Quantitative \\
\hline & (Mir et al., 2016) & 00 & $\begin{array}{l}\text { Journal of Engineering and } \\
\text { Technology Management }\end{array}$ & A1 & Quantitative \\
\hline & $\begin{array}{c}\text { (Palacios- } \\
\text { Marqués et al., 2016) }\end{array}$ & 02 & $\begin{array}{l}\text { Journal of Knowledge } \\
\text { Management }\end{array}$ & $\mathrm{A} 1$ & Quantitative \\
\hline & $\begin{array}{c}\text { (Schneckenberg et al., } \\
\text { 2015) }\end{array}$ & 05 & $\begin{array}{l}\text { Technological Forecasting } \\
\text { and Social Change }\end{array}$ & $\mathrm{A} 1$ & Qualitative \\
\hline & (Vicente et al., 2015) & 03 & $\begin{array}{c}\text { International Marketing } \\
\text { Review }\end{array}$ & $\mathrm{A} 1$ & Quantitative \\
\hline & (Wang \& Dass, 2017) & 00 & $\begin{array}{l}\text { Journal of Business } \\
\text { Research }\end{array}$ & $\mathrm{A} 1$ & Quantitative \\
\hline
\end{tabular}

Source: Elaborated by the authors.

The third phase of this systematic review is the development of reports and understandings on innovation capability. This step refers to data analysis, which was performed through content analysis. Thus, three steps were performed: (1) pre-analysis, (2) material exploration, and (3) treatment of results, inference and interpretation (Bardin, 2006). In the content analysis of the articles analyzed, the research hypothesis helped to delineate search in these texts, thus, four categories emerged: determinants of innovation capability, innovation capability in the internal environment of the company; innovation capability in the company external environment; innovation capability in country contexts and innovation capability in small enterprises. The research results are then presented.

\section{Analysis and discussion of results}

\subsection{Determinants of innovation capability}

Identifying determinants of innovation capability is an important managerial tool, since it indicates the means for organizations to measure their innovation 
capability and helps in the strategy of implementing and improving innovation capability in companies. In Table 2, six publications are shown, based on the criteria already presented in the methodology for the systematic literature review, which proposed determinants for the evaluation of innovation capability and its main application:

Table 2. International Literature on determinants of innovation capability.

\begin{tabular}{|c|c|c|}
\hline AUTHORS & DETERMINANT FACTORS & MAIN APPLICATION \\
\hline (Saunila, 2016). & $\begin{array}{l}\text { Leadership culture, environment and well- } \\
\text { being in the workplace, structural organization, } \\
\text { expertise development, exploration of external } \\
\text { knowledge, regeneration and individual activity }\end{array}$ & $\begin{array}{l}\text { In small companies to } \\
\text { identify the capability to } \\
\text { innovate in products and } \\
\text { processes }\end{array}$ \\
\hline (Vicente et al., 2015) & $\begin{array}{l}\text { Capability for product development, } \\
\text { organizational culture for innovation, strategic } \\
\text { capability and technological capability }\end{array}$ & Exporting companies \\
\hline (Slater et al., 2014) & $\begin{array}{l}\text { Senior leadership, organizational culture, } \\
\text { organizational architecture, the radical process } \\
\text { of product innovation development, and the } \\
\text { product launch strategy }\end{array}$ & $\begin{array}{l}\text { To identify the capability } \\
\text { to innovate in products, } \\
\text { mainly radical } \\
\text { innovations }\end{array}$ \\
\hline $\begin{array}{l}\text { (Frishammar et al., } \\
\text { 2012) }\end{array}$ & Strategy, collaboration and culture & $\begin{array}{l}\text { To identify the capability } \\
\text { for process innovation }\end{array}$ \\
\hline (Fan, 2006) & $\begin{array}{l}\text { Internal factors can be: R\&D and high } \\
\text { employee empowerment. External factors that } \\
\text { promote innovation capability are: government } \\
\text { support, partnership with research institutes, } \\
\text { cooperation with other national and } \\
\text { international companies }\end{array}$ & $\begin{array}{l}\text { For the Industrial sector } \\
\text { and product innovation }\end{array}$ \\
\hline $\begin{array}{l}\text { (Romijn \& } \\
\text { Albaladejo, 2002) }\end{array}$ & $\begin{array}{l}\text { The internal factors are: professional } \\
\text { experience of the owner/manager; workforce } \\
\text { skills; and internal efforts to improve } \\
\text { technology. The external factors are: } \\
\text { relationship intensity in networking; proximity } \\
\text { advantages related to networking; and } \\
\text { government support }\end{array}$ & $\begin{array}{l}\text { Identifying internal and } \\
\text { external factors that } \\
\text { generate innovation } \\
\text { capability for processes } \\
\text { and products }\end{array}$ \\
\hline
\end{tabular}

Source: Elaborated by the authors.

Table 2 shows important contributions to the study on innovation capability. In column 1, we synthesize the factors selected by the authors to study the capability of innovation in organizations. In column 3 , we can visualize the specific sector or type of application is most appropriate for each of the studies evaluated. Each of these studies is then presented.

Few studies have focused on the innovative potential of small businesses. Identifying ways to measure performance of innovations in small businesses could be an important managerial and academic tool. A study based on literature review identified seven determinants to assess innovation capability in small firms: leadership culture; environment and well-being at the workplace; structural organization; expertise development; exploration of external knowledge; regeneration; and individual activity (Saunila, 2016).

Product innovation is the lifeblood of companies competing in dynamic environments. The ability to innovate radically in products is a complex configuration in the organization, which requires an adequate relation of the components: senior leadership, organizational culture, organizational 
architecture, radical process of product innovation development and product launch strategy (Slater et al., 2014).

Process innovation could be an important competitive differential in organizations. From a broad literature review, Frishammar et al. (2012) obtained three factors that contribute to the innovation process: strategy (strategic alignment, portfolio management); collaboration (collaboration between the business units, collaboration with external partners); and culture (innovative environment, commitment and attitudes of top management) (Frishammar et al., 2012).

Similarly, Romijn \& Albaladejo (2002) conducted a broad literature review on determinants of innovation capability and found internal and external factors that may influence the innovation capability in companies. The internal factors are professional experience of the owner/manager, workforce skills, and internal efforts to improve technology. The external factors are relationship intensity in networking, proximity advantages related to networking, and government support (Romijn \& Albaladejo, 2002).

Determinants of innovation capability in industrial telecommunication sectors in China could also be divided into internal factors and external factors. Internal factors could be R\&D and high employee empowerment. The external factors that promote innovation capability are government support, partnership with research institutes and cooperation with other national and international companies (Fan, 2006).

Understanding the multidimensional nature of innovation capability is useful to identify key elements that represent exporting companies in their overall capability to produce innovation results and achieve superior performance. In order to fill this scale gap, innovscale was created. The scale was tested in Portuguese companies by means of a confirmatory factorial analysis (modeling of structural equations with Lisrel software) (Vicente et al., 2015).

Innovscale points that innovation capability is a higher order construction composed of four dimensions: product development capability, organizational culture, strategic and technological capability. The results also indicate that the four dimensions of innovation capability scale are positive and significantly associated with export and export performance (Vicente et al., 2015).

\subsection{Internal factors of innovation capability}

Internal resources for innovation capability were found in several ways in the literature review, namely intellectual capital (Subramaniam \& Youndt, 2005), learning orientation (Calantone et al., 2002), knowledge sharing (Lin, 2007), human and technological aspects (Prajogo \& Ahmed, 2006), total quality management (Perdomo-Ortiz et al., 2006), standardized systems (Mir et al., 2016), predictability (Rohrbeck \& Gemünden, 2011), microfoundations (Schneckenberg et al., 2015), and exploration orientation (Wang \& Dass, 2017). A summary is presented in Table 3 below. 
Table 3. Internal Factors of Innovation Capability.

\begin{tabular}{|c|c|}
\hline $\begin{array}{c}\text { Authors } \\
\text { Internal Factors }\end{array}$ & Short description \\
\hline (Subramaniam \& Youndt, 2005) & \multirow{2}{*}{$\begin{array}{l}\text { Influencing positively the capability for incremental and } \\
\text { radical innovation }\end{array}$} \\
\hline Intellectual capital & \\
\hline (Calantone et al., 2002) & \multirow{2}{*}{$\begin{array}{l}\text { Learning orientation positively influences the innovation } \\
\text { capability and organizational performance }\end{array}$} \\
\hline Guidance for learning & \\
\hline (Lin, 2007) & \multirow{2}{*}{$\begin{array}{l}\text { Human aspects related to information sharing improve } \\
\text { the capability for organizational innovation }\end{array}$} \\
\hline Sharing knowledge & \\
\hline (Prajogo \& Ahmed, 2006) & \multirow{2}{*}{$\begin{array}{l}\text {-Human aspects need to be related to technological } \\
\text { aspects to promote innovation capability }\end{array}$} \\
\hline Human and technological aspects & \\
\hline (Perdomo-Ortiz et al., 2006) & \multirow{2}{*}{$\begin{array}{l}\text { Total Quality Management Systems enhance } \\
\text { organizational innovation capability }\end{array}$} \\
\hline Total Quality Management & \\
\hline (Mir et al., 2016) & \multirow{2}{*}{$\begin{array}{l}\text { Standard Une } 16600 \text { improves organizational innovation } \\
\text { capability }\end{array}$} \\
\hline Standardized systems & \\
\hline (Rohrbeck \& Gemünden, 2011) & \multirow{2}{*}{$\begin{array}{l}\text { The search for accuracy with respect to forecasting } \\
\text {-capability has a provocative role, impelling the } \\
\text { organization to improve its processes }\end{array}$} \\
\hline Forecast Capability & \\
\hline (Schneckenberg et al., 2015) & \multirow{2}{*}{$\begin{array}{l}\text { The specific interactions and interdependencies between } \\
\text { microfoundations in the four categories (organizational, } \\
\text { managerial, organizational, organizational and } \\
\text { organizational structures and processes) improve } \\
\text { organizational innovation capability }\end{array}$} \\
\hline Microfoundations & \\
\hline (Wang \& Dass, 2017) & \multirow{2}{*}{$\begin{array}{l}\text { The effect on exploration by top managers is relatively } \\
\text { stronger when the company has more resources } \\
\text { available and when the environment within the company } \\
\text { is less competitive }\end{array}$} \\
\hline Exploration orientation & \\
\hline
\end{tabular}

Source: Elaborated by the authors.

Most internal factors are related to the human factors in organizations, meaning that companies that have a strategic orientation focused on training personnel for innovation could build innovation capability more easily. Thus, Proposition 1 arises: companies that invest in the human factor, seeking to implement an environment conducive to learning, information sharing, search for intellectual capital and exploration orientation manage to establish companies with improvement of their innovative capability.

In the analysis of internal factors, the capability to innovate, the strategic structural organization and the management model focused on innovation allow companies that have models of organizational management directed to innovation have better conditions to compete. This induces to Proposition 2: organizations with an internal organizational 
environment focused on innovation with well-defined structures, standardized systems, organizational/managerial processes and procedures, and well-designed capabilities of forecasting could more easily gain and sustain their capability for innovation.

\subsection{External factors to innovation capability}

The search for knowledge and skills outside the organization is one of the strategies to build innovation capability. The systematic review found several studies that reported how organizations perceive this issue: strategic alliances (Hagedoorn \& Duysters, 2002; Sen \& Egelhoff, 2000); clusters (Sher \& Yang, 2005); technological parks (Lai \& Shyu, 2005); social responsibility (Lai et al., 2015); forecasting ability (Rohrbeck \& Gemünden, 2011); suppliers (Kulangara et al., 2016; Liu et al., 2015; Swink, 2006); social networks (Palacios-Marqués et al., 2016); communities of practice (Pattinson et al., 2016); and relationship with customers (Foroudi et al., 2016). Each of these publications is detailed in Table 4.

Table 4. External capability for innovation.

\begin{tabular}{|c|c|}
\hline Authors & \\
\hline External Factors & Dinet uesctiption \\
\hline $\begin{array}{l}\text { (Hagedoorn \& Duysters, } \\
\text { 2002; Sen \& Egelhoff, } \\
\text { 2000) }\end{array}$ & \multirow[t]{2}{*}{$\begin{array}{l}\text { Companies use strategic alliances to seek competences in the external } \\
\text { environment in order to improve their innovation capability to create new } \\
\text { products and services }\end{array}$} \\
\hline Strategic alliances & \\
\hline (Sher \& Yang, 2005) & \multirow{2}{*}{$\begin{array}{l}\text { An appropriate level of clustering for R\&D positively influences innovation } \\
\text { capability, however, if exaggerated, clustering produces a negative relation } \\
\text { to innovation capability }\end{array}$} \\
\hline Clustering of companies & \\
\hline (Lai \& Shyu, 2005) & \multirow{2}{*}{$\begin{array}{l}\text { Human resources, research infrastructure, higher level of local customer } \\
\text { demand and better organized local context for the encouragement of } \\
\text { innovation activity favor the innovation capability in technology parks }\end{array}$} \\
\hline Technology parks & \\
\hline (Lai et al., 2015) & \multirow{2}{*}{$\begin{array}{l}\text { Social responsibility has a significant influence on the capability for } \\
\text { corporate innovation, leading to corporate sustainability over the years }\end{array}$} \\
\hline Social responsibility & \\
\hline $\begin{array}{l}\text { (Rohrbeck \& Gemünden, } \\
\text { 2011) }\end{array}$ & \multirow{2}{*}{$\begin{array}{l}\text { In the strategic plan - vision for innovation, providing innovation portfolios } \\
\text { and identifying new business models of competitors. In the initiative plan - } \\
\text { trigger innovation initiatives by identifying new customers and technological } \\
\text { needs, discovering product concepts of competitors }\end{array}$} \\
\hline Forecasting capability & \\
\hline $\begin{array}{l}\text { (Kulangara et al., 2016; } \\
\text { Liu et al., 2015; Swink, } \\
\text { 2006) }\end{array}$ & \multirow{2}{*}{$\begin{array}{l}\text { The involvement of suppliers, without losing the company autonomy, could } \\
\text { increase innovation capability of companies, resulting in greater } \\
\text { development flexibility, better product quality, shorter time for product } \\
\text { development and lower costs }\end{array}$} \\
\hline Suppliers & \\
\hline $\begin{array}{l}\text { (Palacios-Marqués et al., } \\
\text { 2016) }\end{array}$ & \multirow{2}{*}{$\begin{array}{l}\text { Social networks for internal and external cognitive processes positively } \\
\text { affect the knowledge transfer within the organization. This knowledge helps } \\
\text { the company to achieve greater R\&D competence, improving innovation } \\
\text { capability }\end{array}$} \\
\hline Social networks & \\
\hline (Pattinson et al., 2016) & \multirow{2}{*}{$\begin{array}{l}\text { Communities of intra-organizational practice increase knowledge } \\
\text { absorption and improve the innovation capability in companies }\end{array}$} \\
\hline Communities of practice & \\
\hline (Foroudi et al., 2016) & \multirow{2}{*}{$\begin{array}{l}\text { The more the company manages to improve its relationship with the } \\
\text { customer to develop technical and non-technical innovation capability, the } \\
\text { more success the company achieves in achieving customer loyalty and } \\
\text { improving its reputation }\end{array}$} \\
\hline $\begin{array}{l}\text { Relationship with } \\
\text { customers }\end{array}$ & \\
\hline
\end{tabular}

Source: Elaborated by the authors. 
The research results on the external factors of innovation capability have shown that when the company interacts in a strategic and planned way with the most diverse stakeholders, it is possible to acquire knowledge for innovation to improve the business processes and thus be recognized/legitimized by the parties involved. This allows the construction of Proposition 3: companies that strategically relate to their stakeholders in order to acquire knowledge and improve business processes could achieve and maintain their innovation capability.

In an integrative perspective between innovation capability in the internal environment (presented in the previous section) and innovation capability in the external environment, we identified nine dimensions for the evaluation of internal innovation capability (Table 3 ) and nine dimensions for innovation capability in the external environment (Table 4). Thus, 18 different dimensions could be tested in future studies to identify factors that determine the capability of organizational innovation.

\subsection{Innovation capability in small companies and in different countries}

During the systematic literature review, two distinct groups of studies on innovation capability emerged: (1) innovation capability related to small enterprises (Forsman, 2011; Oura et al., 2016; Nassimbeni, 2001); and (2) innovation capability related to countries (Li, 2009; Guan et al., 2006; Khedhaouria \& Thurik, 2017; Wang et al., 2008).

By evaluating the innovation types (radical or incremental) and innovative capability of small manufacturing firms compared to service firms, we identified no significant differences in the degree of innovation capabilities between small service firms and those of manufacturing enterprises. These companies have a low degree of radical innovations, with prevailing incremental innovation (Forsman, 2011).

Small companies aiming to export their products face many challenges, such as having a good capability for innovation and building international export experience. Overcoming these challenges increases the company conditions to compete in the international market (Oura et al., 2016).

In emerging countries like Brazil, innovation capability has a positive impact on export performance and on the international experience in exporting. However, international export experience has a greater impact on export performance than innovation capability. Thus, in the Brazilian context, it is preferable to focus on the international experience of export than on innovation capability to obtain better export performances (Oura et al., 2016).

Small companies may have advantages over larger companies in terms of exports, as they have greater flexibility and operational speed. However, the company that operates in the international market must manage situations of greater complexity, such as language differences, organization of product distribution systems and fierce competition (Nassimbeni, 2001).

Italy has stood out with a large number of companies managing to enter international markets. The success of this internationalization is mainly related to the ability of companies to innovate and develop valid inter-organizational relations, relating in a lesser degree to the company technological profile (manufacturing, quality control, management, design, communication, manipulation, storage technologies) (Nassimbeni, 2001).

Proposition 4: export orientation could be a determining factor for innovation capability in small companies with more specialized needs in their activities. This increases the importance of exporting to small companies that should focus their 
strategies on the relationship with customers, since they have greater flexibility for changes, however, with less technological development and innovations that are more incremental than radical.

Innovation in the different regions of China presents disparities of results and innovation performances in terms of patent counts, varying from region to region. This disparity depends not only on the total amount of R\&D investment, but also on the efficiency of the innovation process in each region. Thus, the more structured and composed the regional innovation activities and the greater the internal innovation capability of companies, the better the results in terms of patents $(\mathrm{Li}, 2009)$.

In China, only $16 \%$ of companies operate positively between technological innovation capability and competitiveness. Thus, the rest of the companies (84\%) need to align the capability of technological innovation with their competitive power in the market (Guan et al., 2006).

National capability for innovation refers to the capability of a country to manage resources and competences to transform existing knowledge into new knowledge, technologies and creative outputs to benefit companies in the service and production sectors and the economy as a whole. Due to the number of factors of analysis, complexity and specificity of each country, an efficient method to analyze the high capability of countries is a fuzzy set. It allows identifying combinations that systematically discriminate the set members that exhibit several levels of results (results of innovation capability) (Khedhaouria \& Thurik, 2017; Wang et al., 2008).

An evaluation carried out in 133 countries and using 74 indicators using the method of fuzzy sets identified five determinant conditions of high innovation capability in countries: strong national institutions, human capital development and research systems, good national infrastructure, facility for business conditions, and a strong market. Some countries such as Estonia, South Korea and Israel have managed to achieve high levels of innovation capability with three conditions: human capital development and research systems, good national infrastructure, and facility for business conditions. Other countries such as Switzerland, Sweden, the Netherlands, the United States, Finland, Singapore, Ireland, Luxembourg and Denmark have achieved high innovation capability by fully meeting the five determinants of innovation (Khedhaouria \& Thurik, 2017).

This information allows the creation of Proposition 5: for companies that want to expand their businesses, a key factor is the achievement of innovation capability aligned with the competitive strategy, seeking regions or countries that have characteristics such as: strong national institutions, development of human capital and research systems, adequate national infrastructure, facility for business conditions and a strong market. Statistical methods, such as the method of fuzzy sets, are indicated to evaluate the region or country to invest.

\section{Final remarks}

This systematic literature review identifies the main contributions regarding innovation capability, selecting 33 articles from the Web of Science database with clear criteria from different journals. These publications were analyzed with due caution in order to bring contributions to innovation capability in the internal and external aspects of the organization, to the determinants of innovation capability applicable to different contexts, and to the innovation capability in the specificities small businesses and in countries. 
Regarding the internal aspects that contribute to the high innovation capability in organizations, three factors stand out in the literature: human resources, technological resources and culture for innovation. Thus, the results obtained suggest that the combination of motivated human talents, with an internal culture focused on innovation, combined with technologies, drives organizations in their innovation capability.

Regarding the external factors that contribute to innovation capability, strategic alliances are highlighted as a tactic for importing knowledge, although companies have more facility to make strategic alliances for product innovation than processes. The literature also shows that the ability to interact with suppliers and customers contributes to knowledge acquisition from outside the organization, improving the ability of the company to innovate. In addition, social networks, technology parks and communities of practice could be managed to acquire expertise.

In six papers, the determinants of innovation capability identified were culture and organizational climate, leadership, structural organization, internal knowledge development, external knowledge exploration (suppliers, clients, partner companies, technology parks, research institutes) strategy, regeneration, and networking. These determinants could be applied to the context of small companies (Saunila, 2016), the industrial sector for product innovation (Fan, 2006), companies that aim to identify the most determinant factors in the export context (Vicente et al., 2015), for innovation of processes (Romijn \& Albaladejo, 2002; Frishammar et al., 2012) and innovation in products (Saunila, 2016; Slater et al., 2014; Romijn \& Albaladejo, 2002; Vicente et al., 2015; Fan, 2006).

This research also highlights based on the literature review that small companies have potential for innovation and export of products and that specific determinants could measure the innovation capability of this category of companies. The study on innovation capability in countries shows that countries should seek alternatives to improve innovation capability of companies as a strategy for economic development.

Although the Web of Science is one of the most complete and used databases, the fact that this database was only used to search for publications is a limitation of the present study. Therefore, it is suggested that future studies broaden the research on innovation capability to other databases, such as Scopus, Emerald. In addition, there is clearly a need for further studies, with the dimensions found in this research, and even studies in the Brazilian business context. The propositions suggested are based on theoretical arguments, which allow analyses of the theoretical content and more empirical tests to better understand innovation capability.

\section{References}

Bardin, L. (2006). Análise de conteúdo (L. A. Rego \& A. Pinheiro, Trads). Lisboa: Edições 70. (Obra original publicada em 1977).

Barney, J. B. (1991). Firm resources and sustained competitive advantage. Journal of Management, 14(1), 99-120. http://dx.doi.org/10.1177/014920639101700108.

Calantone, J. R., Cavusgil, S. T., \& Zhao, Y. (2002). Learning orientation, firm innovation capability, and firm performance. Industrial Marketing Management, 31(6), 515-524. http://dx.doi.org/10.1016/S0019-8501(01)00203-6.

Crossan, M. M., \& Apaydin, M. (2010). A multi-dimensional framework of organizational innovation: A systematic review of the literature. Journal of Management Studies, 47(6), 1154-1191. http://dx.doi.org/10.1111/j.1467-6486.2009.00880.x. 
Fan, P. (2006). Catching up through developing innovation capability: evidence from China's telecom-equipment industry. Technovation, 26(3), 359-368.

http://dx.doi.org/10.1016/j.technovation.2004.10.004.

Foroudi, P., Jin, Z., Gupta, S., Melewar, T. C., \& Foroudi, M. M. (2016). Influence of innovation capability and customer experience on reputation and loyalty. Journal of Business Research, 69(11), 4882-4889. http://dx.doi.org/10.1016/j.jbusres.2016.04.047.

Forsman, H. (2011). Innovation capability and innovation development in small enterprises. A comparison between the manufacturing and service sectors. Research Policy, 40(5), 739750. http://dx.doi.org/10.1016/j.respol.2011.02.003.

Frishammar, J., Kurkkio, M., Abrahamsson, L., \& Lichtenthaler, U. (2012). Antecedents and consequences of firms' process innovation capability : a literature review and a conceptual framework. IEEE Transactions on Engineering Management, 59(4), 519-529. http://dx.doi.org/10.1109/TEM.2012.2187660.

Guan, J. C., Yam, R. C. M., Mok, C. K., \& Ma, N. (2006). A study of the relationship between competitiveness and technological innovation capability based on DEA models. European Journal of Operational Research, 170(3), 971-986. http://dx.doi.org/10.1016/j.ejor.2004.07.054.

Hagedoorn, J., \& Duysters, G. (2002). External sources of innovative capabilities: the preference for strategic alliances or mergers and acquisitions. Journal of Management Studies, 39(2), 167-188. http://dx.doi.org/10.1111/1467-6486.00287.

Henderson, R. M., \& Clark, K. B. (1990). Architectural innovation: the reconfiguration of existing product technologies and the failure of established firms. Administrative Science Quarterly, 9-30.

Khedhaouria, A., \& Thurik, R. (2017). Configurational conditions of national innovation capability: a fuzzy set analysis approach. Technological Forecasting and Social Change, 120, 48-58. https://doi.org/10.1016/j.techfore.2017.04.005.

Kogut, B., \& Zander, U. (1992). Knowledge of the firm, combinative capabilities, and the replication of technology. Organization Science, 3(3), 383-397. http://dx.doi.org/10.1287/orsc.3.3.383.

Kulangara, N. P., Jackson, S. A., \& Prater, E. (2016). Examining the impact of socialization and information sharing and the mediating effect of trust on innovation capability. International Journal of Operations \& Production Management, 36(11), 1601-1624. http://dx.doi.org/10.1108/IJOPM-09-2015-0558.

Lai, H. C., \& Shyu, J. Z. (2005). A comparison of innovation capability at science parks across the Taiwan Strait: The case of Zhangjiang High-Tech Park and Hsinchu Science-based Industrial Park. Technovation, 25(7), 805-813. http://dx.doi.org/10.1016/j.technovation.2003.11.004.

Lai, W. H., Lin, C. C., \& Wang, T. C. (2015). Exploring the interoperability of innovation capability and corporate sustainability. Journal of Business Research, 68(4), 867-871. http://dx.doi.org/10.1016/j.jbusres.2014.11.043.

Lawson, B., \& Samson, D. (2001). Developing innovation capability in organisations: a dynamic capabilities approach. International Journal of Innovation Management, 5(3), 377-400. http://dx.doi.org/10.1142/S1363919601000427.

$\mathrm{Li}, \mathrm{X}$. (2009). China's regional innovation capability in transition: an empirical approach. Research Policy, 38(2), 338-357. http://dx.doi.org/10.1016/j.respol.2008.12.002.

Lin, H. F. (2007). Knowledge sharing and firm innovation capability: an empirical study. International Journal of Manpower, 28(3-4), 315-332. http://dx.doi.org/10.1108/01437720710755272.

Liu, X., Huang, Q., Dou, J., \& Zhao, X. (2015). The impact of informal social interaction on innovation capability in the context of buyer-supplier dyads. Journal of Business Research, 78, 314-322. https://doi.org/10.1016/j.jbusres.2016.12.027. 
Mir, M., Casadesús, M., \& Petnji, L. H. (2016). The impact of standardized innovation management systems on innovation capability and business performance: an empirical study. Journal of Engineering and Technology Management, 41, 26-44. http://dx.doi.org/10.1016/j.jengtecman.2016.06.002.

Nassimbeni, G. (2001). Technology, innovation capability, and the export attitude of small manufacturing firms : a logit $r$ tobit model. Research Policy, 30(2), 245-262. http://dx.doi.org/10.1016/S0048-7333(99)00114-6.

Oura, M. M., Zilber, S. N., \& Lopes, E. L. (2016). Innovation capability, international experience and export performance of SMEs in Brazil. International Business Review, 25(4), 921-932. http://dx.doi.org/10.1016/j.ibusrev.2015.12.002.

Palacios-Marqués, D., Popa, S., \& Pilar Alguacil Mari, M. (2016). The effect of online social networks and competency-based management on innovation capability. Journal of Knowledge Management, 20(3), 499-511. http://dx.doi.org/10.1108/JKM-05-2015-0175.

Pattinson, S., Preece, D., \& Dawson, P. (2016). In search of innovative capabilities of communities of practice: A systematic review and typology for future research. Management Learning, 47(5), 506-524. http://dx.doi.org/10.1177/1350507616646698.

Perdomo-Ortiz, J., González-Benito, J., \& Galende, J. (2006). Total quality management as a forerunner of business innovation capability. Technovation, 26(10), 1170-1185. http://dx.doi.org/10.1016/j.technovation.2005.09.008.

Prajogo, D. I., \& Ahmed, P. K. (2006). Relationships between innovation stimulus, innovation capability, and innovation performance. $R$ \& D Management, 36(5), 499-515. http://dx.doi.org/10.1111/j.1467-9310.2006.00450.x.

Rohrbeck, R., \& Gemünden, H. G. (2011). Corporate foresight: its three roles in enhancing the innovation capability of a firm. Technological Forecasting and Social Change, 78(2), 231243. http://dx.doi.org/10.1016/j.techfore.2010.06.019.

Romijn, H., \& Albaladejo, M. (2002). Determinants of innovation capability in small electronics and software firms in southeast England. Research Policy, 31(7), 1053-1067. http://dx.doi.org/10.1016/S0048-7333(01)00176-7.

Saunila, M. (2016). Performance measurement approach for innovation capability in SMEs Minna. International Journal of Productivity and Performance Management, 65(2), 162-176. http://dx.doi.org/10.1108/IJPPM-08-2014-0123.

Schneckenberg, D., Truong, Y., \& Mazloomi, H. (2015). Microfoundations of innovative capabilities: the leverage of collaborative technologies on organizational learning and knowledge management in a multinational corporation. Technological Forecasting and Social Change, 100, 356-368. http://dx.doi.org/10.1016/j.techfore.2015.08.008.

Sen, F. K., \& Egelhoff, W. G. (2000). Innovative capabilities of a firm and the use of technical alliances. IEEE Transactions on Engineering Management, 47(2), 174-183. http://dx.doi.org/10.1109/17.846785.

Sher, P. J., \& Yang, P. Y. (2005). The effects of innovative capabilities and R\&D clustering on firm performance: the evidence of Taiwan's semiconductor industry. Technovation, 25(1), 33-43. http://dx.doi.org/10.1016/S0166-4972(03)00068-3.

Slater, S. F., Mohr, J. J., \& Sengupta, S. (2014). Radical product innovation capability: literature review, synthesis, and illustrative research propositions. Journal of Product Innovation Management, 31(3), 552-566. http://dx.doi.org/10.1111/jpim.12113.

Subramaniam, M., \& Youndt, M. A. (2005). The Influence of Intellectual Capital on the Types of Innovative Capabilities Linked references are available on JSTOR for this article: the influence of intellectual capital on the types of innovative capabilities. Academy of Management Journal, 48(3), 450-463. http://dx.doi.org/10.5465/amj.2005.17407911.

Swink, M. (2006). Building collaborative innovation capability. Research Technology Management, 49(2), 37-47. http://dx.doi.org/10.1080/08956308.2006.11657367. 
Teece, D., Pisano, G., \& Shuen, A. (1997). Dynamic capabilities and strategic management. Strategic Management Journal, 18(7), 509-533. http://dx.doi.org/10.1002/(SICl)10970266(199708)18:7<509::AID-SMJ882>3.0.CO;2-Z.

Tranfield, D., Denyer, D., \& Smart, P. (2003). Towards a methodology for developing evidenceinformed management knowledge by means of systematic review. British Journal of Management, 14(3), 207-222. http://dx.doi.org/10.1111/1467-8551.00375.

Valladares, P. S. D. A., Vasconcellos, M. A., \& Di Serio, L. C. (2014). Capacidade de inovação: revisão sistemática da literatura. Revista de Administração Contemporânea, 18(5), 598626.

Vicente, M., Abrantes, J. L., \& Teixeira, M. S. (2015). Measuring innovation capability in exporting firms: the INNOVSCALE. IInternational Marketing Review, 32, 29-51.

Wang, C.-H., Lu, I.-Y., \& Chen, C.-B. (2008). Evaluating firm technological innovation capability under uncertainty. Technovation, 28(6), 349-363. http://dx.doi.org/10.1016/j.technovation.2007.10.007.

Wang, X., \& Dass, M. (2017). Building innovation capability: the role of top management innovativeness and relative-exploration orientation. Journal of Business Research, 76, 127135. http://dx.doi.org/10.1016/j.jbusres.2017.03.019.

Wernerfelt, B. (1984). A resource-based view of the firm. Strategic Management Journal, 5(2), 171-180. http://dx.doi.org/10.1002/smj.4250050207. 